\title{
ANALISIS PENGARUH KEMISKINAN, INDEKS PEMBANGUNAN MANUSIA (IPM) DAN TENAGA KERJA TERHADAP PERTUMBUHAN EKONOMI DI JAWA TIMUR
}

\author{
Amita Prameswari \\ Email: 17011010072@student.upnjatim.ac.id \\ Ekonomi Pembangunan/Fakultas Ekonomi dan Bisnis/Universitas Pembangunan Nasional \\ "Veteran" Jawa Timur \\ Sri Muljaningsih \\ Email: sri.muljaningsih.ep@upnjatim.ac.id \\ Ekonomi Pembangunan/Fakultas Ekonomi dan Bisnis/Universitas Pembangunan Nasional \\ "Veteran" Jawa Timur \\ Kiki Asmara \\ Email: kikiasmara.ep@upnjatim.ac.id \\ Ekonomi Pembangunan/Fakultas Ekonomi dan Bisnis/Universitas Pembangunan Nasional \\ "Veteran" Jawa Timur
}

\begin{abstract}
ABSTRAK
Pembangunan suatu negara tidak terlepas peran dari pemerintahan daerah merupakan suatu bagian yang tidak kalah penting dalam memanfaatkan potensi sumber daya yang terdapat didalamnya secara maksimal. Penelitian ini bertujuan untuk mengetahui pengaruh antara Kemiskinan, Indeks Pembangunan Manusia (IPM), dan Tenaga Kerja terhadap Pertumbuhan Ekonomi di Jawa Timur. Metode yang digunakan adalah metode kuantitatif dengan analisis regresi berganda dan data runtut waktu. Secara simultan Kemiskinan, Indeks Pembangunan Manusia (IPM), dan Tenaga Kerja secara bersama-sama berpengaruh positif dan signifikan terhadap Pertumbuhan Ekonomi di Jawa Timur. Secara parsial variabel Kemiskinan berpengaruh secara positif dan signifikan terhadap Pertumbuhan Ekonomi di Jawa Timur, sedangkan variabel Indeks Pembangunan Manusia (IPM) dan Tenaga Kerja berpengaruh secara negatif dan signifikan terhadap Pertumbuhan Ekonomi di Jawa Timur.

Kata Kunci: Pertumbuhan Ekonomi, Kemiskinan, Indeks Pembangunan Manusia (IPM), dan Tenaga Kerja

\section{ABSTRACT}

The development of a country cannot be separated from the role of regional government which is no less important in utilizing the potential of the resources contained in it to the fullest. This study aims to determine the effect of Poverty, Human Development Index (IPM), and Labor on Economic Growth in East Java. The method used is a quantitative method with multiple regression analysis and time series data. Simultaneously Poverty, Human Development Index (IPM), and Labor together have a positive and significant effect on Economic Growth in East Java. Partially (T test) Poverty variable has a positive and significant effect on Economic Growth in East Java, while the Human Development Index (IPM) and Labor variables have a negative and significant effect on Economic Growth in East Java.
\end{abstract}

Keywords: Economic Growth, Poverty, Human Development Index (HDI), and Labor 


\section{PENDAHULUAN}

Dalam waktu yang jangka panjang pasti setiap negara mempunyai tujuan yang paling utama yaitu adanya pertumbuhan dalam perekonomiannya. Sebagai negara yang masih terbilang belum maju dalam kesejahteraan perekonomiannya maka dalam mewujudkan kesejahteraan tersebut Indonesia harus dapat mengupayakan pertumbuhan ekonominya (Dewi and Cahyono, 2016). Dalam mewujudkannya maka harus terdapat perubahan yang kompleks dari berbagai hal seperti politik, social, budaya, ekonomi, dan pertahanan keamanannya sehingga perubahannya dapat dirasakan oleh seluruh masyarakat, kebutuhan masyarakat juga dapat terpenuhi sehingga masyarakat yang makmur dan adil dapat terwujud sesuai dengan harapan suatu negara didirikan (Latuconsina, 2017).

Dalam meningkatkan pendapatan suatu negara maka peran pemerintahan dalam daerah merupakan suatu bagian yang tidak kalah penting dalam memanfaatkan potensi sumber daya yang terdapat didalamnya secara maksimal. Selain pertumbuhan ekonomi, Kemiskinan juga merupakan the oldest problem yang dialami semua negara, dengan tingkat kesejahteraan yang berbeda pula cluster masyarakat dikategorikan oleh indeks pembangunan manusia yang dimana peran serta tenaga kerja juga dibutuhkan dalam faktor produksi yang dapat menunjang pertumbuhan ekonomi. Dalam Pembukaan UUD 1945 alinea "4" tertulis tujuan luhur bangsa bahwa kesejahteraan dan kecerdasan adalah hak bangsa yang artinya adalah hal untuk seluruh rakyat, dimana kedua hal tersebut sangat berkaitan dengan pertumbuhan ekonomi yang artinya, pertumbuhan ekonomilah yang mejadi tujuan dari bangsa Indonesia itu sendiri, Pertumbuhan ekonomi sendiri itu ialah suatu hal yang prosesnya bersifat berkelanjutan yang mempengaruhi perubahan keadaan ekonomi sepanjang periode tertentu (Rakhmawati, 2016) yang memiliki keterkaitan dengan tingkat kesejahteraan masyarakat, hingga ketenaga kerjaan.

Berdasar pada penelitian yang dilakukan oleh Dewi dkk (2016) mempunyai hasil bahwa jumlah kemiskinan bernilai negative dan secara signifikan apabila masih banyak jumlah orang miskin yang ada maka hal ini dapat menghambat percepatan laju ekonomi suatu negara. Sehingga, dalam proses pembangunan suatu negara adanya kemiskinan merupakan permasalahan yang harus segera diatasi dikarenakan nasib perekonomian suatu negara dapat tergantung pada tingkat kemiskinan didalamnya. 
Pertumbuhan ekonomi di Jawa Timur setiap tahunnya selalu menunjukan nilai positif yang artinya bahwa kenaikan terus terjadi. Data dari BPS Jatim dari 2005 sampai dengan 2019 bahwa nilai PDRB Jawa Timur terus mengalami peningkatan. Hal tersebut tentunya disebabkan oleh beberapa faktor yang menunjang peningkatan pertumbuhan ekonomi di setiap tahunnya. Akan tetapi, masih tersimpan beberapa hambatan maupun permasalahan yang bisa menjadi penyebab penurunan PDRB tersebut, jadi pemerintah harus mengupayakan dalam pencarian solusi maupun upaya dalam mempertahankan strategi secara berkesinambungan agar peningkatan pertumbuhan ekonomi tetap berlangsung (Kemiskinan et al., 2015).

Melihat keterkaitan tersebut, tumbuhnya perekonomian menjadi hal utama dalam meningkatkan kesejahteraan masyarakatnya, pertumbuhan ekonomi yang terjadi, tidak hanya di pengaruhi dari pendapatan daerah maupun anggaran desentralisasi, akan tetapi terdapat permasalahan makro seperti Indeks Pembangunan Manusia, Ketenaga Kerjaan dan menurunnya angka kemiskinan. Dari asumsi tersebut peneliti tertarik melakukan penelitian mengenai seberapa besar Pengaruh Kemiskinan, Indeks Pembangunan Manusia (IPM), dan Tenaga Kerja terhadap Pertumbuhan Ekonomi di Jawa Timur

\section{Gambar 1 Kemiskinan, Indeks Pembangunan Manusia, Tenaga Kerja, dan Pertumbuhan Ekonomi Provinsi Jawa Timur}

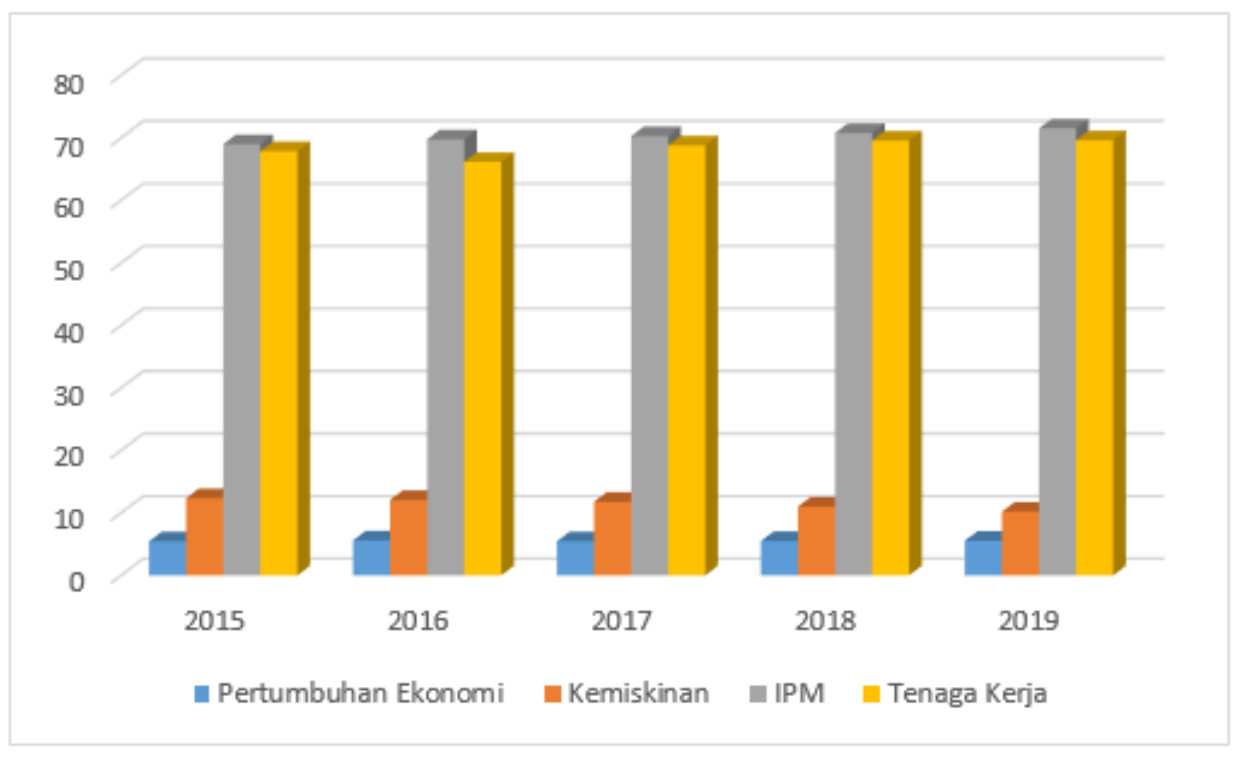

Sumber: BPS Jawa Timur 2020 (data diolah)

Dari gambar bisa dilihat jika tingkat pertumbuhan ekonomi di Provinsi Jawa Timur selama kurun waktu 2015-2019 terus mengalami kenaikan. Pertumbuhan ekonomi Provinsi Jawa Timur 
tahun 2015 sebesar 1.331.376,1 Milyar dengan tingkat pertumbuhan yaitu sebesar 5.44\%, angka ini terus mengalami peningkatan sampai dengan tahun 2019 yaitu sebesar 1.650.143,15 Milyar dengan tingkat pertumbuhan sebesar 5,52\%. Hal ini dapat dikarenakan Provinsi Jawa Timur mengandalkan konsumsi rumah tangga yang sharenya mencapai 59\%. Jadi, apabila konsumsi rumah tangga bagus, maka pertumbuhan ekonomi juga bagus.

Kemiskinan diartikan sebagai kondisi masyarakat dalam keadaan ekonomi yang rendah. Standart kondisi ini secara tidak langsung besar pengaruhnya terhadap tingkat kesehatan, pendidikan dan gaya hidup mereka yang masuk kategori sebagai orang miskin atau hidup dalam kemiskinan, mereka yang terkategori miskin, kemiskinan ialah suatu yang sesungguhnya terjadi dalam kehidupan mereka setiap hari, karena mereka itu merasakan serta menjalani sendiri hidup dalam kemiskinan (Paramita. and Purbadharmaja., 2013).

Kemikinan di Provinsi Jawa Timur dalam kurun 5 tahun terakhir terus menunjukkan penurunan yang signifikan. Dapat dilihat dari tahun 2015 jumlah penduduk miskin Provinsi Jawa Timur sebanyak 4.476 jiwa dari 38.847.561 jiwa total penduduk Jawa Timur, dan total penduduk miskin Provinsi Jawa Timur setiap tahunnya terus menurun sampai dengan tahun 2019 dengan total penduduk Jawa Timur sebanyak 39.698.631 jiwa, jumlah penduduk miskin pada saat itu sebanyak 4.056 jiwa, dengan tingkat kemiskinan sebesar 10,37\%. Hal tersebut menunjukkan jika pemerintah Provinsi Jawa Timur berperan aktif dalam pengentasan kemiskinan. Turunnya tingkat kemiskinan di Provinsi Jawa Timur dikarenakan terus meningkatnya angka pertumbuhan ekonomi. Sehingga, dengan meningkatnya angka pertumbuhan ekonomi justru akan mengurangi jumlah penduduk miskin di Provinsi Jawa Timur dan secara tidak langsung tingkat kesejahteraan meningkat.

Pemerintah selaku pelaksana pembangunan pastinya memerlukan modal manusia yang berkualitas. Dalam upaya mengembangkan Sumber Daya Manusia yang berkualitas memerlukan usaha untuk meningkatkan kualitas SDMnya, adapaun kualitas Sumber Daya Manusia bisa diukur dengan Indeks Pembangunan Manusia (Dewi, Yusuf and Iyan, 2016). Indeks Pembangunan Manusia Provinsi Jawa Timur selama periode waktu 2015-2019 terus menunjukkan peningkatan yang cukup singifikan. Pada tahun 2015 tingkat indeks pembangunan manusia (IPM) Provinsi Jawa Timur sebesar 68,95\%, kemudian terus mengalami peningkatan sampai pada tahun 2018 sebesar 70,77, dan terus meningkat sampai di tahun 2019 yaitu sebesar 71,5\%. Berdasarkan kategori yang diberikan oleh UNDP, capaian pembangunan manusia di Provinsi Jawa Timur 
termasuk dalam kategori sedang $(60 \leq \mathrm{IPM}<70)$ setiap tahunnya. Meningkatnya angka pembangunan manusia ini menunjukkan bahwa Provinsi Jawa Timur dari segi pendidikan, kesehatan, dan kualitas hidup layak dikatakan cukup bagus.

Selain masalah kemiskinan dan kualitas Sumber Daya Manusia (SDM), tenaga kerja merupakan salah satu aspek yang mempengaruhi pertumbuhan ekonomi. Peran tenaga kerja tersebut sebagai salah satu faktor produksi yang mempengaruhi terhadap tingkat pendapatan nasional dari segi kuantitas. Angkatan kerja dan penyerapan tenaga kerja di Provinsi Jawa Timur pada tahun 2015-2019 cenderung fluktuatif. Jumlah angkatan kerja di Provinsi Jawa Timur sebanyak 20.274.681 jiwa. Pada tahun 2016 turun menjadi 19.953.846 Jiwa, kemudian pada tahun 2017 naik menjadi 20.937.716 jiwa, angka ini terus mengalami peningkatan sampai dengan tahun 2019 menjadi 21.867.742 jiwa. Peningkatan ini akan lebih baik apabila terjadi peningkatan pula pada lapangan kerja yang tersedia, sehingga nantinya akan menyerap tenaga kerja agar mendapatkan pekerjaan. Banyakanya kesempatan kerja yang tersedia di lapangan akan mendorong pertumbuhan ekonomi di daerah tersebut. Peningkatan pertumbuhan ekonomi mencerminkan kemakmuran suatu masyarakat yang meningkat, sehingga hal ini menyebabkan tersedianya lapangan pekerjaan sehingga tingkat pengangguran akan berkurang (Lincolin, 2010).

\section{METODE PENELITIAN}

Metode penelitian dalam penelitian ini menggunakan metode kuantitatif. Analisis data dalam penelitian ini adalah menggunakan metode analisis regresi linier berganda dengan asumsi klasik dengan data runtut waktu (time series)

Dengan rumus umum regresi linier berganda yang digunakan yaitu:

$$
\mathrm{Y}=\mathrm{a}+\mathrm{b}_{1} \mathrm{X}_{1}+\mathrm{b}_{2} \mathrm{X}_{2}+\ldots+\mathrm{b}_{\mathrm{n}} \mathrm{X}_{\mathrm{n}}
$$

\section{Keterangan:}

$$
\begin{array}{ll}
\mathrm{Y} & =\text { Variabel Terikat } \\
\mathrm{X} & =\text { Variabel Bebas } \\
\mathrm{a} & =\text { Konstanta } \\
\mathrm{b} & \quad=\text { Koefisien Regresi pada masing-masing variabel bebas }
\end{array}
$$




\section{BLUE (Best Linier Unbiased Estimate)}

Dalam melakukan pengujian menggunakan Uji Simultan (F) dan Uji Parsial (T) maka data yang digunakan dalam penelitian itu tidak diperbolehkan bias. Dalam melakukan ujia BLUE ada beberapa hal yang harus diperhatikan, yaitu adanya tiga asumsi dimana data yang akan digunakan harus lolos ketiganya terlebih dahulu yang kemudian dapat dilanjutkan dipengujian berikutnya, ketiga asumsi itu diantaranya, yaitu:

\section{a. Lolos Uji Autokorelasi}

Dalam sebuah data yang sifatnya beruntut waktu (time series) biasanya saling berhubungan sehingga apabila terdapat data yang eror pada periode tertentu dengan periode lainnya. sehingga adanya hal ini dapat membuat data menjadi bias yang dapata mempengaruhi koefisien dan nilai variansnya. (Gujarati,2003)

\section{b. Lolos Multikolinearitas}

Dalam sebuah pengujian yang menunjukan pengaruh antar variabel yang digunakan. Maka dengan itu kedua variabel baik terikat maupun bebas yang digunakan dalam pengujian tidak boleh bersifat linear. Hal yang harus diperhatikan dalam pengujian ini adalah nilai dari VIF yang tidak boleh lebih dari 10. (Gujarati, 2009)

\section{c. Lolos Uji Heteroskedastisitas}

Melalui uji ini akan diketahui ada atau tidaknya ketidakcocokan pada varian dari sebuah residual dalam satu penelitian dengan penelitian yang lainnya. Apabila dalam penelitian terdapat varian yang tidak sama maka disebut heterokedastisitas (Ghozali, (2016)

\section{Uji Statistik}

a. Koefisien Determinasi $\left(\mathrm{R}^{2}\right)$

Koefisien determinasi dimana apabila mempunyai nilai yang mendekari 100 maka model tersebut dapat diterima dan layak untuk dilanjutkan. (Ghazali, 2013)

b. Uji Simultan (Uji F)

Uji ini dilakukan untuk melihat berapa besar semua variabel bebas dapat mempunyai pengaruh terhadap variabel terikat dengan melihat nilai signifikansi (Ghazali, 2013).

\section{c. Uji Parsial (Uji T)}

Uji ini dilakukan untuk melihat bagaimana pengaruh satu persatu variabel bebas terhadap variabel terikat. Sehingga dapat diketahui bagaimana pengaruh masing-masing variabel bebas dapat mempengaruhi variabel bebas dan menjawab hipotesis. (Ghazali, 2013) 


\section{HASIL DAN PEMBAHASAN}

\section{HASIL}

\section{Asumsi BLUE (Best Linies Unbiased Estimator)}

Uji Autokorelasi

Gambar 1 Kurva Statistik Durbin-Watson

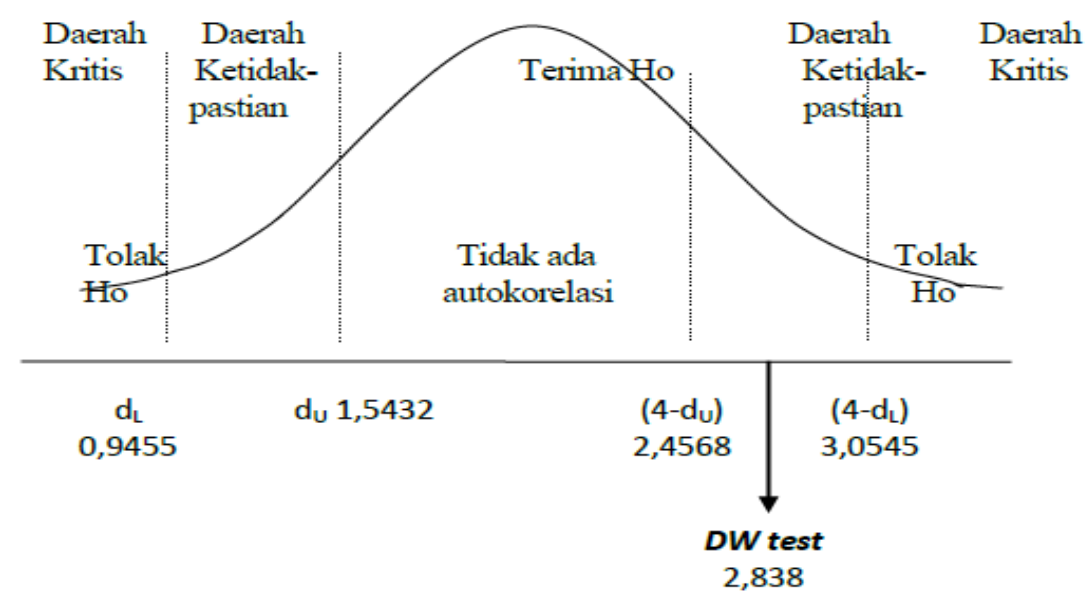

Sumber: Data Diolah dengan SPSS 13;

Dari hasil perhitungan Durbin-Watson, posisi nilai DW test sebesar 2,838. Sehingga, dapat diartikan bahwa pada model uji ini bebas dari autokorelasi dikarenakan nilai DW test berada di daerah ketidakpastian.

\section{Uji Multikolinieritas}

Tabel 1 Uji Multikolinearitas

\begin{tabular}{|c|c|c|c|c|c|}
\hline Variabel Y & $\begin{array}{c}\text { VIF } \\
(\mathrm{X} 1)\end{array}$ & $\begin{array}{c}\text { VIF } \\
(\mathrm{X} 2)\end{array}$ & $\begin{array}{c}\text { VIF } \\
(\mathrm{X} 3)\end{array}$ & Ketentuan & Keterangan \\
\hline $\begin{array}{c}\text { Pertumbuhan } \\
\text { Ekonomi }\end{array}$ & 2,013 & 1,355 & 2,403 & $\leq 10$ & $\begin{array}{c}\text { Tidak Terjadi Gejala } \\
\text { Multinolinearitas }\end{array}$ \\
\hline
\end{tabular}

Sumber: Data Diolah dengan SPSS 13; Lampiran 3, 2021

Berdasarkan pengujian diatas, mendapatkan hasil bahwa dari ketiga varibel dalam pengujian nilai Pertumbuhan Ekonomi di Provinsi Jawa Timur, dihasilkan semua variabel bebas mempunyai nilai inflation vactor yang kurang dari $(\leq) 10$ pada nilai sig. a 0,05 . Sehingga pengujian yang dilakukan dinyatakan bebas dari multikolinieritas. 


\section{Uji Heterokedastisitas}

Tabel 2 Uji Heterokedastisitas

\begin{tabular}{|c|c|c|c|c|c|}
\hline Variabel Y & $\begin{array}{c}\text { Sig 2- tailed } \\
(\mathrm{X} 1)\end{array}$ & $\begin{array}{c}\text { Sig 2- tailed } \\
(\mathrm{X} 2)\end{array}$ & $\begin{array}{c}\text { Sig 2-tailed } \\
(\mathrm{X} 3)\end{array}$ & Ketentuan & Keterangan \\
\hline $\begin{array}{c}\text { Pertumbuhan } \\
\text { Ekonomi }\end{array}$ & 0,950 & 0,830 & 0,909 & $\geq 0,05$ & Tidak Terjadi \\
& & & & & Gejala \\
& & & & & \\
\hline
\end{tabular}

Sumber: Data Diolah dengan SPSS 13

Berdasarkan table, diperoleh hasil nilai residual ketiga variabel bebas lebih besar dari 0,05 yang berarti bahwa ketiga variabel bebas terbebas dari heterokedastisitas.

\section{Uji Statistik}

\section{Koefisien Determinasi $\left(\mathbf{R}^{2}\right)$}

Tabel 3 Koefisien Determinasi

\begin{tabular}{|c|c|c|}
\hline R Square & F Change & Durbin - Watson \\
\hline 0,958 & 83,030 & 2,838 \\
\hline
\end{tabular}

Sumber: Data Diolah dengan SPSS 13

Nilai $\mathrm{R}^{2}$ sebesar 0,958, artinya seluruh variabel bebas (Kemiskinan, IPM, dan Tenaga Kerja) mampu menjelaskan variabel terikatnya (Pertumbuhan Ekonomi) sebesar 95,8\%, sedangkan sisanya dijelaskan dengan faktor lain.

Uji F

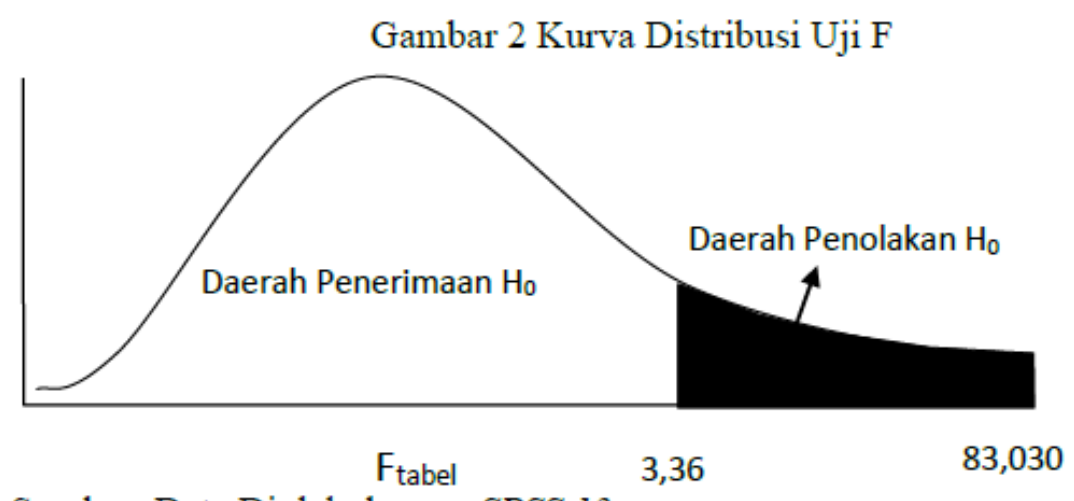

Sumber: Data Diolah dengan SPSS 13 


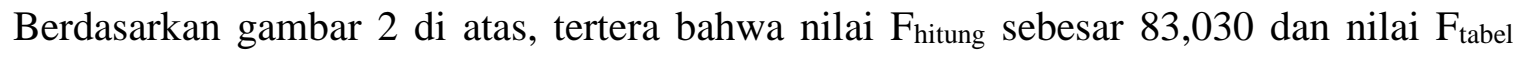
sebesar 3,36 maka $F_{\text {hitung }} 83,030>\mathrm{F}_{\text {tabel }}$ 3,36 serta nilai probabilitas menunjukkan bahwa 0,000 < $\alpha$ 0,05. Berdasarkan hipotesis, maka bisa diartikan telah terjadi penolakan Ho dan penerimaan $\mathrm{H}_{1}$ sehingga dapat diartikan bahwa dalam penelitian ini menunjukkan pengaruh yang signifikan antara variabel independen terhadap variabel dependen.

Uji T

Gambar 3 Kurva Distribusi Kemiskinan terhadap Pertumbuhan Ekonomi

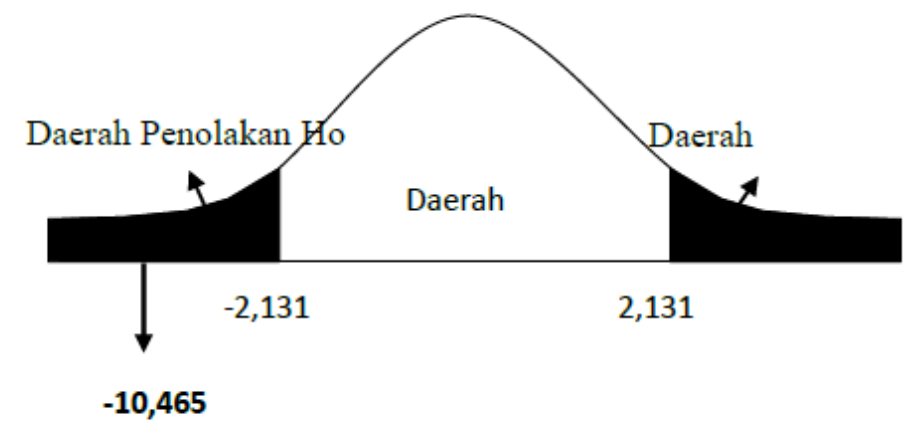

Sumber: Data Diolah dengan SPSS 13;

Berdasarkan gambar diatas, menunjukkan bahwa t-hitung sebesar -10,465 dan t-tabel 2,131 maka $t_{\text {hitung }}-10,465>t_{\text {tabel }}$ serta nilai probabilitas menunjukkan $0,000>\alpha 0,05$. Sehingga bisa diartikan bahwa variabel Kemiskinan memiliki pengaruh yang signifikan terhadap variabel dependen yaitu Pertumbuhan Ekonomi di Provinsi Jawa Timur.

Gambar 4 Kurva Distribusi IPM terhadap Pertumbuhan Ekonomi

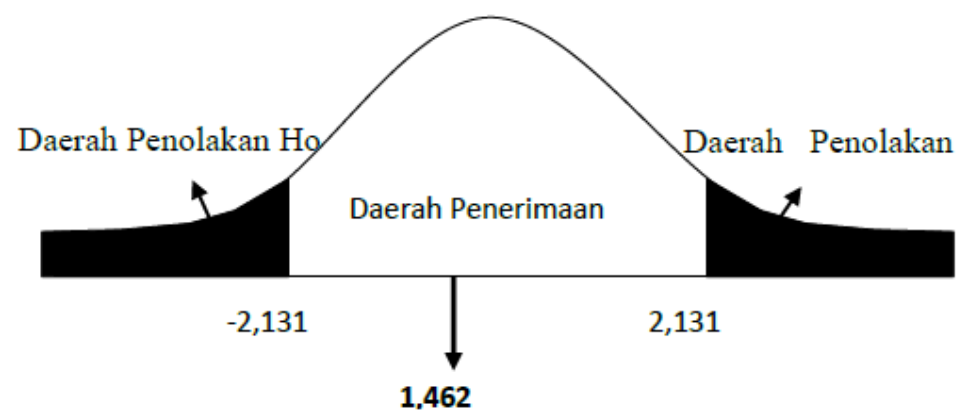

Sumber: Data Diolah dengan SPSS 13

Berdasarkan gambar diatas, menunjukkan bahwa t-hitung sebesar 1,462 dan t-tabel 2,131 maka $t_{\text {hitung }} 1,462>\mathrm{t}_{\text {tabel }}$ serta nilai probabilitas menunjukkan 0,172 yang lebih besar dari 0,05. Sehingga dapat diartikan bahwa terdapat pengaruh yang tidak signifikan antara variabel 
independen yaitu Indeks Pembangunan Manusia (IPM) terhadap variabel dependen yaitu Pertumbuhan Ekonomi di Provinsi Jawa Timur.

Gambar 5 Kurva Distribusi Tenaga Kerja terhadap Pertumbuhan Ekonomi

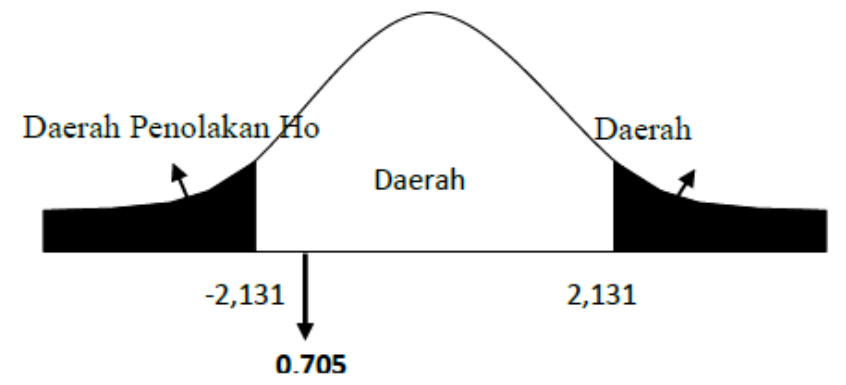

Sumber: Data Diolah dengan SPSS 13

Berdasarkan gambar diatas, menunjukkan bahwa t-hitung sebesar 0,705 dan t-tabel 2,131 maka $t_{\text {hitung }} 0,705>t_{\text {tabel }}$ serta nilai probabilitas menunjukkan 0,495 lebih besar dari 0,05. Sehingga dapat diartikan bahwa terdapat pengaruh yang tidak signifikan antara variabel independen yaitu Tenaga Kerja terhadap variabel dependen yaitu Pertumbuhan Ekonomi di Provinsi Jawa Timur.

\section{PEMBAHASAN}

\section{Pengaruh Variabel Kemiskinan Terhadap Pertumbuhan Ekonomi}

Terdapat pengaruh negatif pada variabel kemiskinan (X1) terhadap pertumbuhan ekonomi (Y), pada taraf nyata 5\% diketahui bahwa kemiskinan berpengaruh yang secara signifikan terhadap pertumbuhan ekonomi

Hasil ini sesuai dengan penelitian yang pernah dilakukan oleh (Kemiskinan et al., 2015) yang menyatakan bahwa kemiskinan merupakan permasalahan hambatan dalam menuju pertumbuhan ekonomi.Tingkat pertumbuhan ekonomi yang naik akan memberikan kesempatan pada perusahaan untuk meningkatkan penyerapan tenaga kerja sehingga memberikan peluang kerja pada masyarakat. Jika penduduk miskin semakin banyak, maka keikut sertaan dalam menunjang pertumbuhan ekonomi di daerah akan semakin berkurang dan menghambat pertumbuhan ekonomi di wilayah tersebut. Menurut Kuncoro (2005) terdapat suatu hubungan yang negatif antara pertumbuhan ekonomi dan kemiskinan. Pertumbuhan ekonomi yang meningkat akan mengurangi kemiskinan. Sehingga, dalam hubungan ini menunjukkan pentingnya peran pemerintah dalam mempercepat laju pertumbuhan ekonomi agar dapat mengurangi angka kemiskinan. 


\section{Pengaruh Variabel Indeks Pembangunan Manusia (IPM) Terhadap Pertumbuhan Ekonomi}

Terdapat pengaruh yang positif pada variabel IPM (X2) dan pertumbuhan ekonomi (Y), namun dalam pengujian ini indeks pembangunan manusia tidak signifikan dalam mempengaruhi pertumbuhan ekonomi.

Pernyataan ini sesuai dengan (Priestnall et al., 2020) dimana penelitiannya menunjukkan pengaruh yang tidak signifikan antara indeks pembangunan manusia dalam mempengaruhi pertumbuhan ekonomi. Hal tersebut sejalan dengan penjelasan Constantini V. dan M. Salcatore yang menjelaskan bahwa apabila pembangunan sumber daya manusia mengalami peningkatan maka akan berpengaruh juga pada peningkatan secara ekonominya karena keberadaan Sumber Daya Manusia yang berkualitas dapat memberikan kontribusi yang nyata bagi tumbuhnya suatu perekonomian, meskipun pada kenyataan pertumbuhan ekonomi memiliki hubungan yang dual causation dengan Indeks Pembangunan Manusia yang dimana setiap daerah memiliki hasil tersendiri akibat dari perbedaan komposisi tiga komponen IPM tersebut dalam mempengaruhi Pertumbuhan Ekonomi di suatu wilayah tersebut.

\section{Pengaruh Variabel Tenaga Kerja terhadap Pertumbuhan Ekonomi}

Terdapat pengaruh yang positif Tenaga Kerja (X3) terhadap variabel Pertumbuhan ekonomi (Y), namun dalam penelitian ini menunjukkan jika tenaga kerja tidak mempunyai pengaruh yang signifikan terhadap variabel Pertumbuhan Ekonomi (Y). Pertumbuhan ekonomi yang meningkat mencerminkan kemakmuran masyarakat yang mengalami peningkatan pula, hal ini akan menyebabkan banyaknya lapangan pekerjaan yang tersedia sehingga akan mengurangi angka pengangguran (Lincolin, 2010).

Hal tersebut sesuai dengan (Priestnall et al., 2020) yang menyatakan bahwa tenaga kerja memiliki pengaruh positif yang tidak signifikan terhadap pertumbuhan ekonomi di Provinsi Jawa Timur. Hal tersebut diakibatkan banyaknya sumber daya manusia yang berkualitas maka mereka dapat menciptakan mesin yang lebih maju sehingga dapat memberikan inovasi dalam perkembangan teknologi dimana teknologi ini digunakan untuk membantu kehidupan manusia dalam sehari-hari.

\section{KESIMPULAN DAN SARAN}

\section{Kesimpulan}

Variabel Kemiskinan merupakan variabel yang paling berpengaruh negatif dan signifikan terhadap laju pertumbuhan ekonomi di Provinsi Jawa Timur, maka dari itu pemerintah harus 
mempersiapkan program-program yang dapat mengentaskan masyarakat dari kemiskinan, mulai dari bantuan langsung tunai, hingga dukungan modal untuk usaha menengah kecil agar dapat dikembangkan dan keluar dari kungkungan kemiskinan.

\section{Saran}

Pemerintah dapat mempersiapkan program-program unggulan lainnya untuk mempersiapkan kesiapan tenaga kerja dalam memasuki dunia kerja maupun pelatihan berwirausaha dan lainnya agar dapat membuka lapangan pekerjaan baru guna dapat berinovasi dan berkontribusi dalam pertumbuhan ekonomi di Provinsi Jawa Timur sehingga biaya kebutuhan sehari hari dapat tercukupi, kesehatan dan kesejahteraan dapat terjamin yang pada akhirnya akan membuat taraf indeks pembangunan manusia yang meningkat dibarengi oleh pertumbuhan ekonomi yang juga akan meningkat karena maksimumnya daya sokong dari beberapa sumber yang menunjang terjadinya pertumbuhan ekonomi. Ketiga hal tersebut tidak dapat dipisahkan jauh dari unsur partumbuhan ekonomi sehingga pemerintah dapat secara matang memperhitungkan program yang dapat meningkatkan kemampuan para tenaga kerja agar dapat bekerja dengan tujuan mengurangi kemiskinan dan berakhir dengan peningkat indeks pembangunan manusia dan secara autopilot pertumbuhan ekonomi dapat bertumbuh secara otomatis.

\section{DAFTAR PUSTAKA}

Dewi, T. M. and Cahyono, H. (2016) 'Pengaruh Pertumbuhan Ekonomi, Bi Rate, Dan Inflasi Terhadap Investasi Asing Langsung Di Indonesia', Jurnal Pendidikan Ekonomi (JUPE), 4(3), pp. 1-7.

Kemiskinan, P. et al. (2015) 'Pengaruh Kemiskinan, Pertumbuhan Ekonomi, Dan Belanja Modal Terhadap Ipm Jawa Tengah', Pengaruh Kemiskinan, Pertumbuhan Ekonomi, Dan Belanja Modal Terhadap Ipm Jawa Tengah, 4(2), pp. 102-113. doi: 10.15294/jejak.v4i2.4645.

Latuconsina, Z. M. Y. (2017) 'Analisis Faktor-faktor yang Mempengaruhi Indeks Pembangunan Manusia Kabupaten Malang Berbasis Pendekatan Perwilayahan dan Regresi Panel', Journal of Regional and Rural Development Planning, 1(2), p. 202. doi: 10.29244/jp2wd.2017.1.2.202-216.

Priestnall, S. L. et al. (2020) 'Analisis Pengaruh Indeks Pembangunan Manusia, Tenaga Kerja, dan Kemiskinan terhadap Perumbuhan Ekonomi', Endocrine, 9(May), p. 6. Available at: https://www.slideshare.net/maryamkazemi3/stability-of colloids\%0Ahttps://barnard.edu/sites/default/files/inline/student_user_guide_for_spss.pdf \%0Ahttp://www.ibm.com/support\%0Ahttp://www.spss.com/sites/dmbook/legacy/ProgDa taMgmt_SPSS17.pdf\%0Ahttps://www.n.

Rakhmawati, R. (2016) 'Pengaruh Indeks Pembangunan Manusia (IPM), Tenaga Kerja, Dan Pendidikan Terhadap Pertumbuhan Ekonomi Di Provinsi Jawa Tengah', Ekonomi Pembangunan, (2016), pp. 1-16. 